\title{
Véralvadásgátló hatású pentaszacharidok moduláris szintézise
}

\author{
MEZÖ Erika* \\ DE-GYTK Gyógyszerészi Kémiai Tanszék, Egyetem tér 1., 4032 Debrecen, Magyarország
}

\section{Bevezetés}

A heparin glükózamin és hexuronsav (d-glükuronsav és 1-iduronsav) egységekböl felépülö polianionos, lineáris poliszacharid, mely a sejtek felületén és az extracelluláris mátrixban fordul elő proteoglikánok formájában. Antikoaguláns hatását az antitrombin (szerin-proteáz inhibitor) allosztérikus aktiválásával fejti ki. ${ }^{1}$ A hatás kiváltásához elengedhetetlen a molekulán belül előforduló egyedi pentaszacharid szekvencia (1, DEFGH) jelenléte, melynek anionos jellegű csoportjai (szulfátészter/karboxil) erős ionos kölcsönhatásokat alakítanak ki az antitrombin bázikus csoportjaival. A pentaszacharid egy szintetikusan előállított változatát 2001 óta alkalmazzák a gyógyászatban Arixtra $^{\circledR}$ (2) néven. ${ }^{2-4} \mathrm{Az}$ elmúlt másfél évtizedben a vegyület számos mimetikumát állították elő, melyek elődjüknél egyszerübben és könnyebben szintetizálhatóak voltak. A vezérmolekula teljesen $O$-metilezett és $O$-szulfatált változata az idraparinux (3), ${ }^{5,6}$ mely kiemelkedő antikoaguláns aktivitással rendelkezik (1. ábra).
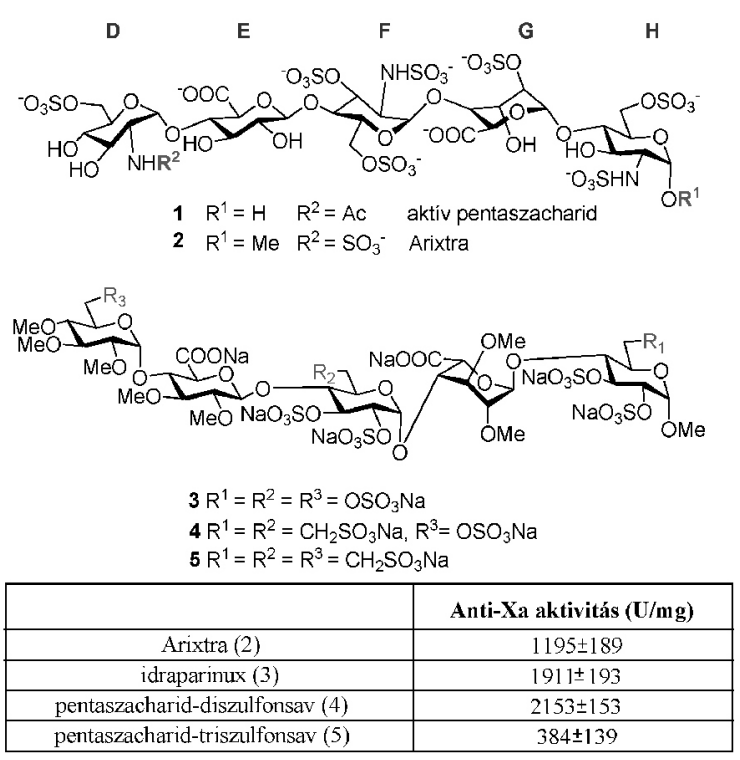

1. Ábra. / 1. Táblázat. A heparin antikoaguláns hatású doménje (1) és szintetikus származékai $(2,3)$ valamint a korábban elöállított pentaszacharid-szulfonsavak $(\mathbf{4}, \mathbf{5})$ szerkezete

Az elmúlt években a kutatócsoportunk két pentaszacharid szulfonsavat állított elő, melyeken az F, H és a D, F, H glükóz egységek 6- $O$-szulfát-csoportjait metánszulfonsavra cserélték. Az in vitro vizsgálatok során a vegyületek antikoaguláns aktivitása jelentős eltérést mutatott. A diszulfonsav származék (4) hatékonyabb volt a referencia vegyületeknél (2, 3), a pentaszacharid-triszulfonsav (5) viszont lényegesen kisebb aktivitást mutatott (1. ábra). ${ }^{7}$

Látva, hogy a lecserélni kívánt szulfát-észter csoportok helyzete és száma meghatározó a vegyületek aktivitását illetően, elhatároztuk újabb izoszter szulfonsav származékok szintézisét, és antikoaguláns hatásának vizsgálatát. Doktoranduszi kutatásom keretében feladatom volt az idraparinux primer helyzetü szulfátészter csoportjainak szisztematikus cseréjével a 6-10 mono- és diszulfonsavak szintézise (2. ábra).

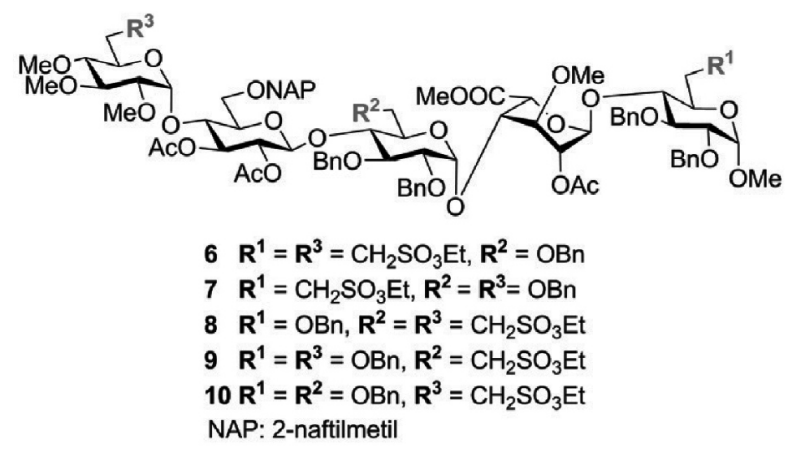

2. Ábra. A tervezett védett di- és monoszulfonsav-pentaszacharidok szerkezete

Feladatul kaptam továbbá az 5-ös pentaszacharidtriszulfonsav hatékonyabb útvonalon történő előállítását is nagyobb mennyiségben, fehérje-kötődési vizsgálatok céljából.

\section{Eredmények}

A tervezett pentaszacharid sorozat retroszintetikus analízise alapján moduláris szintézistervet dolgoztam ki, amely szerint valamennyi vegyület előállítható néhány közös di- és triszacharid építőelem felhasználásával. A reakciótervet követve a szintézishez nyolc monoszacharid építőelem szükséges: 2 uronsav prekurzor, 3-3 szulfonsav-tartalmú és szulfonsavat nem tartalmazó glükóz származék. Ezek kombinációjából két DE diszacharid donor és három FGH triszacharid akceptor modul építhető fel, melyek [2+3]-as glikozilezési reakciójával előállítható a védett pentaszacharidsorozat (3. ábra).

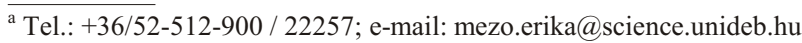




\subsection{Az építőelemek előállítása}

A szulfonátometil-csoport tartalmazó vegyületek nagy mennyiségü szintézisére hatékony módszert dolgoztam ki, hogy elegendő mennyiségben rendelkezésre álljon valamennyi pentaszacharid szintéziséhez.

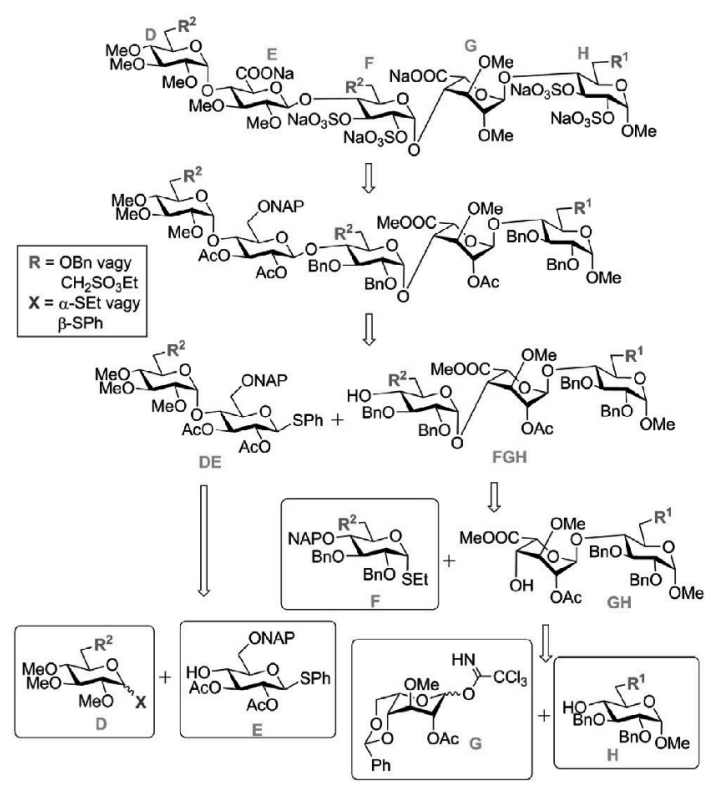

3. Ábra. A C6-szulfonsav-tartalmú pentaszacharidok sorozatának retroszintetikus analízise

Mind a három monoszacharid-szulfonsavat lítiált metánszulfonsav-etilészterrel végzett nukleofil szubsztitúciós reakcióban állítottam elő a megfelelő glükozid-6-O-triflát származékokból. Azt tapasztaltam, hogy $O$-glükozidok szintézisére kiválóan alkalmas ez a módszer és a H-egységet (15) közel 10 grammos mennyiségben szintetizáltam. A 14-es vegyület szintézisét a 12 6-dezoxi-6-jód származékon keresztül is megvalósítottam, de jóval szerényebb hozamot sikerült így elérnem, mint a jobb távozó csoportot tartalmazó 13 triflát-származékkal (4. ábra).

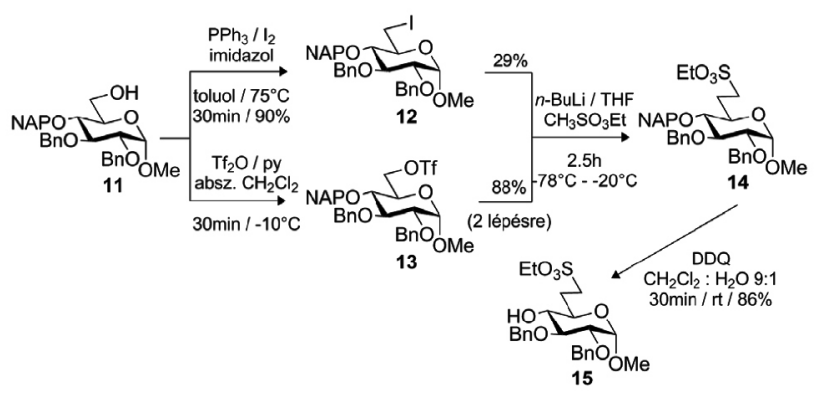

4. Ábra. A szulfonsav-tartalmú H-egység szintézisének optimalizálása

A szulfonsav-tartalmú tioglikozid $\mathbf{F}$ donort szintézisét (5. ábra) $\alpha$-tioglikozidból kiindulva valósítottam meg. ${ }^{8} \mathrm{~A}$ reakcióút során kétféle időleges védőcsoportot is kipróbáltam. Megfigyeltem, hogy a nukleofil csere a 2-naftilmetil-éter védőcsoportot tartalmazó 21-es származék-kal nagyon jó hozammal müködött, míg a p-metoxibenzil (PMB) származék (22) esetében jelentős mennyiségü bomlástermék képződését tapasztaltam. Így a várt terméket csak alacsony hozammal sikerült izolálni. Ezért az $\mathbf{F}$ építőelem szintézisét a 2-naftilmetil védőcsoport alkalmazásával valósítottam meg.

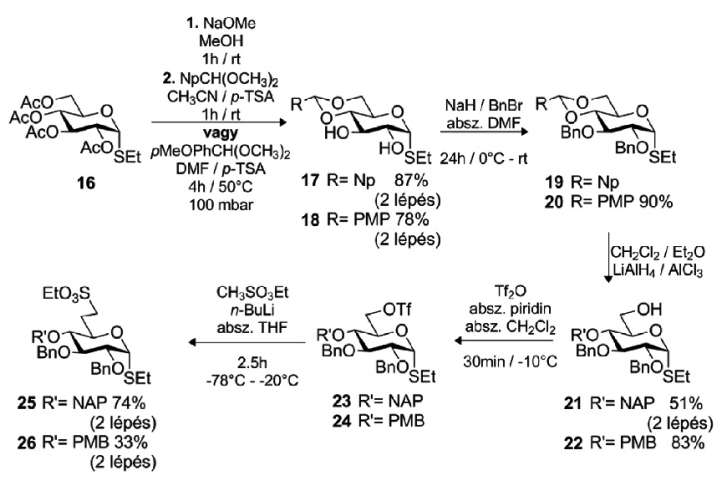

5. Ábra. A szulfonsav-tartalmú F monoszacharid donor szintézise

A korábbi vegyületek szintézise során nyert tapasztalatokat felhasználva a szulfonsav tartalmú D-egység szintézisét szintén $\alpha$-tioglikozidból (16) valósítottam meg (6. ábra). A nukleofil szubsztitúció kiváló hozammal müködött, és a várt terméket több mint 10 grammos tételben sikerült szintetizálni.

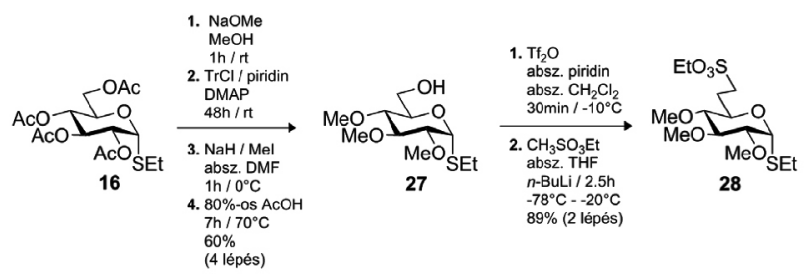

6. Ábra. A szulfonsav-tartalmú D-egység szintézise

\subsection{A di- és triszacharid modulok felépítése}

A D-egységen szulfonsavat tartalmazó pentaszacharidokhoz $(\mathbf{6}, \mathbf{8}, \mathbf{1 0})$ szükséges 32-es DE diszacharid donor szintézisére hatékony kemoszelektív glikozilezési módszert dolgoztam ki (7. ábra). A reakciókörülények optimálása során az 31-es tioglikozid akceptort ${ }^{9}$ különböző glikozil donorokkal reagáltattam $\left(\mathbf{2 8}, \mathbf{2 9},{ }^{10} \mathbf{3 0}\right)$.
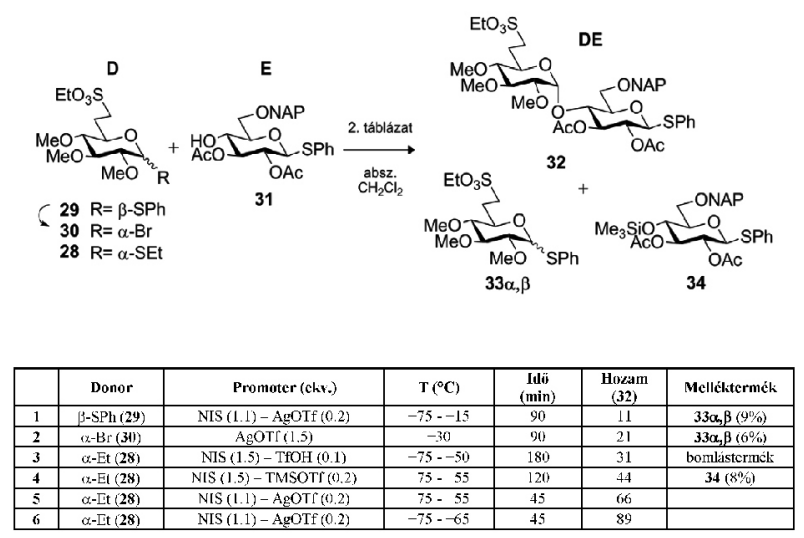

7. Ábra. / 2. Táblázat Szulfonsav-tartalmú DE diszacharid donor szintézise és a reakciókörülmények 
Az 1.-es és 2.-es sorszámú reakciók esetén glikozil transzfer $(33 \alpha, \beta)$ melléktermék képződését tapasztaltam, ami gyakori mellékreakció tioglikozid akceptorokkal végzett glikozilezési reakciókban (7. ábra). ${ }^{11-15} \mathrm{~A}$ mellék-termék elkerülésére különböző anomer távozó csoportokat és promoter rendszereket is kipróbáltam. NIS-TMSOTf promoter eleggyel végzett glikozilezési reakcióban a glikozil akceptor szililezett termékét (34) is izoláltam melléktermékként. A leghatékonyabb donor az etil- $\alpha$-tioglikozid (28) volt, melyet NIS-AgOTf promoter rendszerrel aktiváltunk alacsony hőmérsékleten, így a kívánt diszacharidot (32) $89 \%$-os hozammal nyertük.

A szulfonsavas és a szulfonsavat nem tartalmazó H-egységeket $\left(\mathbf{1 5}, \mathbf{3 5}^{16}\right)$ glikozileztem az iduronsav prekurzorával (34), és így előállítottam kétféle GH diszacharidot $(36,37 ; 8$. ábra $)$. A karboxil-csoportot a szénhidrátok ezen formájában, diszacharid szinten alakítottam ki $(\mathbf{4 0 , 4 1 )}$.
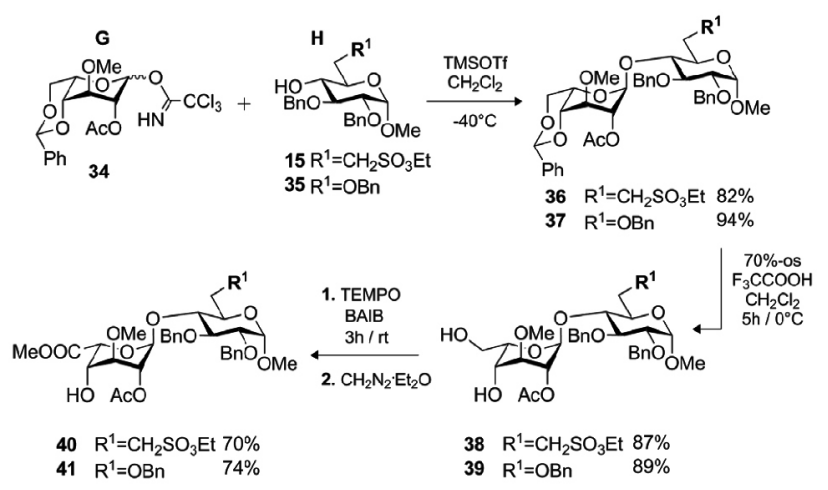

8. Ábra. A GH épitőelemek szintézise

A védett pentaszacharidokhoz szükséges FGH triszacharidok prekurzorait (47-50) a 40-es és 41-es GH diszacharid akceptorok szulfonsav-tartalmú és szulfonsav nélküli glikozil donorokkal (28, 42 $\left.{ }^{17}\right)$ történő glikozilezésé-vel állítottam elő (9. ábra). A kapcsolási reakciók egy kivételével kiváló hozammal müködtek, az aktiválására NIS-TfOH promoter elegyet alkalmaztam.

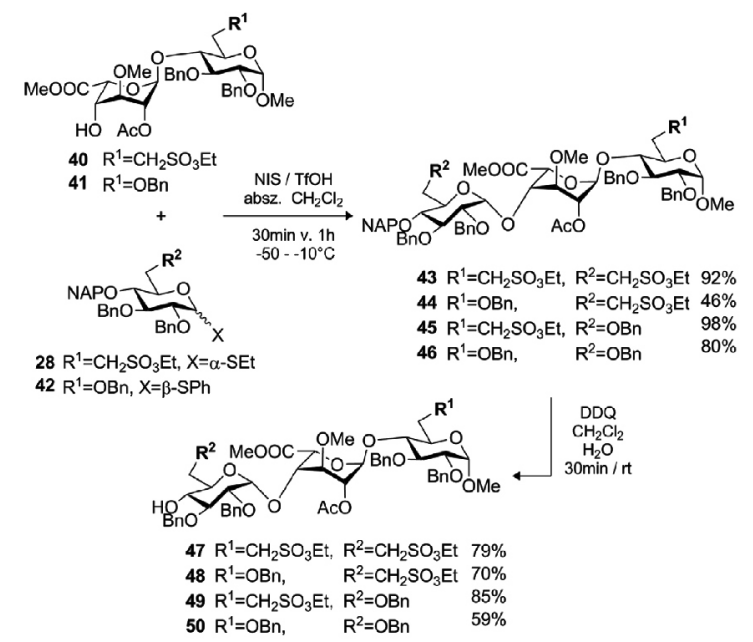

9. Ábra. Az FGH építőelemek szintézise
A 44-es triszacharid hozamát NIS-AgOTf promoter rendszerrel 73\%-ra tudtuk növelni. A triszacharidokról oxidatív módon távolítottam el a (2-naftil)metil-éter védőcsoportot, a termékeket közepes és jó hozamokkal kaptam. A változó hozamok azzal magyarázhatók, hogy a 30 perces reakció során a konverzió nem mindig teljes, ugyanakkor a reakcióidö növekedésével a benzil-csoportok lehasadása is megkezdődik.

\subsection{A védett pentaszacharid származékok előállítása glikozilezési reakciókban}

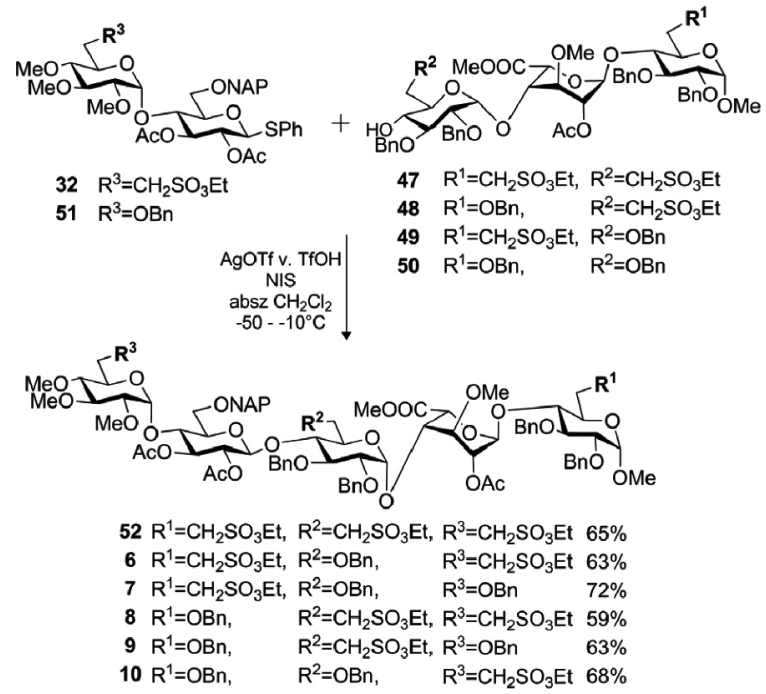

10. Ábra. A védett pentaszacharidok előállítása

A négy FGH triszacharid akceptor (47-50) és a két DE diszacharid donor $\left(\mathbf{3 2}, \mathbf{5 1}^{18}\right)$ glikozilezésével előállítottam az öt új védett pentaszacharidot (6-10) valamint a korábban más reakcióúton elóállított pentaszacharid-triszulfonsavat (52; 10. ábra). A glikozilezési reakciók jó hozammal teljes sztereoszelektivitással mentek végbe.

\subsection{A pentaszacharid-triszulfonsav szintézise}

A munkám második részeként az 52-es pentaszacharidból 8 lépésben előállítottam az 5-ös pentaszacharid-triszulfonsavat közel 100 mg mennyiségben (11. ábra).

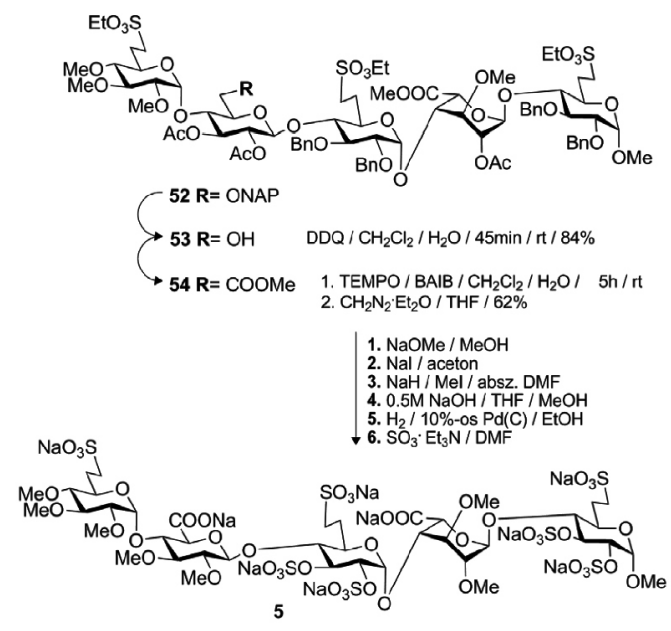

11. Ábra. A védett pentaszacharid-triszulfonsav (52) átalakítása végtermékké 
Az általam elöállított vegyülettel együttmüködő partnereink elvégezték a szénhidrát-antitrombin komplex részletes NMR-vizsgálatát és molekuladinamika szimuláció segítségével meghatározták a szabad és az AT-hoz kötött pentaszacharid konformációs adatait (12. Ábra).

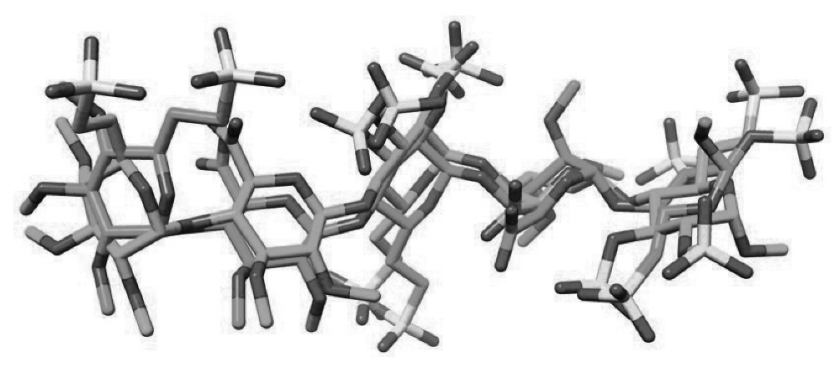

12. Ábra. Az 5-ös pentaszacharid-triszulfonsav antitrombinhoz kötött (kék) és szabad állapotú formájának (zöld) molekulamodellje

Az így nyert eredmények azt mutatták, hogy a fehérjéhez kötött és a szabad állapotú forma szerkezete jelentősen eltér egymástól. Így a gyenge antikoaguláns hatás azzal magyarázható, hogy a fehérjéhez történő bekötődés jelentős változást igényel a konformációban. (A pentaszacharid bekötődése a fehérjéhez a DEF triszacharidon indul meg. ${ }^{19,20}$ Így feltételezhető, hogy már a dokkolás megkezdődésénél vannak problémák.)

\subsection{A pentaszacharid-diszulfonsav szintézise}

A továbbiakban célul tüztük ki valamennyi védett pentaszacharid végtermékké alakítását. Ennek első fázisaként a 8-as származékból ( $\mathbf{D}$ és $\mathbf{F}$ egységén tartalmaz szulfonátometil csoportot) előállítottam az első új pentaszacharid-diszulfonsav végterméket (13. Ábra).

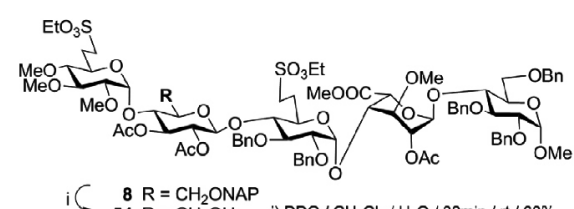

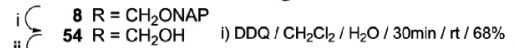

ii $\begin{array}{ll}54 \mathrm{R}=\mathrm{CH}_{2} \mathrm{OH} & \text { i) } \mathrm{DDQ} / \mathrm{CH}_{2} \mathrm{Cl}_{2} / \mathrm{H}_{2} \mathrm{O} / 30 \mathrm{~min} / \mathrm{rt} / 68 \% \\ 55 \mathrm{R}=\mathrm{COONa} & \text { ii) } \mathrm{TEMPO} / \mathrm{BAIB} / \mathrm{CH}_{2} \mathrm{Cl}_{2} / \mathrm{H}_{2} \mathrm{O} / 24 \mathrm{~h} / \mathrm{rt} / 80 \%\end{array}$

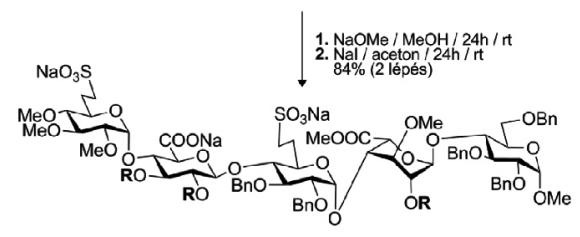

iiiC $\begin{array}{ll}56 \mathrm{R}=\mathrm{H}^{2} \\ 57 \mathrm{R}=\mathrm{CH}_{3} & \text { iii) Mel } / \mathrm{NaH} / \mathrm{DMF} / 4 \mathrm{~h} / 0^{\circ} \mathrm{C} / 55 \%\end{array}$

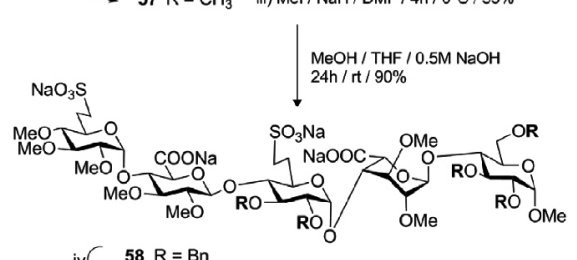

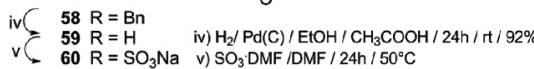

13. Ábra. A védett pentaszacharid-diszulfonsav (8) átalakítása végtermékké

\section{Köszönetnyilvánítás}

Köszönetet elsősorban témavezetőmnek Prof. Dr. Borbás Anikónak szeretném kifejezni önzetlen segítségéért és támogatásáért. A laborban nyújtott segítségét szeretném megköszönni Dr. Herczeg Mihály tudományos munka-társnak. Köszönetemet szeretném kifejezni Prof. Dr. E. Kövér Katalinnak az NMR-vizsgálatokért és $D r$. Komáromi Istvánnak vegyületeim molekulamodellezésért. Köszönettel tartozom a TÁMOP 4.2.4.A/2-11-1-2012-0001 azonosító számú Nemzeti Kiválóság Programnak, és a Richter Gedeon Talentum Alapítványnak a doktori tanulmányaim-hoz nyújtott anyagi támogatásért. A kutatás anyagi támogatását a Mizutani Foundation for Glycoscience (150091) és az OTKA (PD115645) biztosította. 


\section{Hivatkozások}

1. Gandhi, N. S.; Manecera, R. L. Drug Discov. Today 2010, $15,1058-1067$. https://doi.org/10.1016/j.drudis.2010.10.009

2. Chang, C.-H., Lico, L. S., Huang, T.-Y., Lin, S.-Y., Chang, C.-L., Arco, S. D., Hung, S.-C. Angew. Chem. Int. Ed., 2014, 53, 9876-9879.

https://doi.org/10.1002/anie.201404154

3. Lin, F., Lian, G., Zhou, Y. Carbohydr Res. 2013, 371, 32-39. https://doi.org/10.1016/j.carres.2013.01.003

4. Manikowski, A., Koziol, A., Czajkowska-Wojciechowska E. Carbohydr Res., 2012, 361, 155-161. https://doi.org/10.1016/j.carres.2012.08.020

5. Westerduin, P., van Boeckel, C. A. A., Basten, J. E. M., Broekhoven, M. A., Lucas, H., Rood, A., van der Heijden, H., van Amsterdam, R. G. M., van Dinther, T. G., Meuleman, D. G., Visser, A., Vogel, G. M. T., Damm, J. B. L., Overklift, G. T. Bioorg. Med. Chem. 1994, 2 , $1267-1280$ https://doi.org/10.1016/S0968-0896(00)82078-7

6. Lin, F., Lian, G., Zhou, Y. Carbohydr Res. 2013, 371 , 32-39. https://doi.org/10.1016/j.carres.2013.01.003

7. Herczeg, M., Lázár, L., Bereczky, Zs., Kövér, K. E., Timári,I., Kappelmayer, J., Lipták, A., Antus, S., Borbás, A. Chem.-Eur. J., 2012, 18, 10643-10652. https://doi.org/10.1002/chem.201201041

8. Herczeg, M., Mező, E., Eszenyi, D., Lázár, L., Csávás, M., Bereczki, I., A., Antus, S., Borbás, A. Eur. J. Org. Chem., 2013, 25, 5570-5573.

Https://doi.org/10.1002/ejoc.201300681

\section{Modular synthesis of anticoagulant pentasaccharides}

Heparin has been present on the market for decades until today and is one of the most often applied anticoagulants, even though it has a number of limitations including the risk of life-threatening heparin-induced thrombocytopaenia. Heparin is a sulfated glycosaminoglycan (GAGs) consisting of $1 \rightarrow 4$ linked hexuronic acids (D-glucuronic and L-iduronic acids in a ratio of 1:9) and glucosamine with varying degrees of sulfation. This negatively charged linear polysaccharide is found inside cells and in the extracellular matrix. It is an indirect inhibitor of trombin through binding to antithrombin (AT, a serine protease inhibitor) which is a regulator protein in the coagulation cascade. Presence of unique pentasaccharide unit (DEFGH, 1) within a polysaccharide is nessecery for the anticoagulant effect. Its synthetic analogue (2, fondaparinux sodium) has been used under the name Arixtra ${ }^{\circledR}$ in the medicine since 2001. Some analogues of fondaparinux were prepared in the last decades. One of the most promising molecules is idraparinux (3) which is a non-glycosaminoglycan analogue of fondaparinux and it is a more easier obtainable derivative. Its main advantage is the excellent anticoagulation effect (Scheme 1.).

The aim of my $\mathrm{PhD}$ project was the preparation of this series of pentasaccharide sulfonic acids (6-10) in protected form (Scheme 2.) which can be transformed into isosteric sulfonic acid analogues of the anticoagulant pentasaccharide
9. Lázár L., Mező E., Herczeg M., Lipták A., Antus S., Borbás A. Tetrahedron, 2012, 68, 7386-7399. https://doi.org/10.1016/j.tet.2012.06.081

10. Herczeg, M., Lázár, L., Bereczky, Zs., Kövér, K. E., Timári,I., Kappelmayer, J., Lipták, A., Antus, S., Borbás, A. Chem.-Eur. J., 2012, 18, 10643-10652.

https://doi.org/10.1002/chem.201201041

11. Mező, E., Herczeg, M., Eszenyi, D., Borbás, A. Carbohydr. Res., 2014, 388, 19-29.

https://doi.org/10.1016/j.carres.2014.02.012

12. Yu, F. Nguyen, H. M. J. Org .Chem., 2012, 77, 7330-7343. https://doi.org/10.1021/jo301050q

13. Peng, P., Xiong, D.C., Ye, X. S. Carbohydr. Res., 2014, 384, 1-8. https://doi.org/10.1016/j.carres.2013.11.009

14. Manabe, S., Ishii, K., Ito, Y.J. Org. Chem., 2007, 72, 6107-6115. https://doi.org/10.1021/jo070669p

15. Li, Z., Gildersleeve, J. C. J. Am. Chem. Soc., 2006, 128, 11612-11619. https://doi.org/10.1021/ja063247q

16. Ek, M.; Garegg, Per J.; Hultberg, H.; Oscarson, S. J. Carbohydr. Chem. 1983, 2, 305-311. https://doi.org/10.1080/07328308308057876

17. Motawia, M. S.; Olsen, C. E.; Enevoldsen, K.; Marcussen, J.; Moiler, B. L. Carbohydr. Res., 1995, 277, 109-123. https://doi.org/10.1016/0008-6215(95)00203-6

18. Lázár L., Mező E., Herczeg M., Lipták A., Antus S., Borbás A. Tetrahedron, 2012, 68, 7386-7399. https://doi.org/10.1016/j.tet.2012.06.081

19. Scheidin-Weiss, S.; Richard, B.; Olson, S.T. Arch Biochem. Biophys. 2010, 169-176. https://doi.org/10.1016/j.abb.2010.08.021

20. Langdown, J.; Belzar, K.J.; Savory, W.T.; Baglin, T.P.; Huntington, J.A. J. Mol. Biol. 2009, 1278-1289. https://doi.org/10.1016/j.jmb.2009.01.028

idraparinux. Moreover, we also aimed at preparing the pentasaccharide trisulfonic acid $\mathbf{5}$ in a sufficient amount for detailed STD NMR studies of its interactions with antithrombin.

We elaborated a modular synthetic pathway to obtain the new pentasaccharides 5-10 containing C6-sulfonic acid moieties (Scheme 3.). Based on the retrosynthetic analysis the target molecules can be disconnected to two $\mathbf{D E}$ dissacharide donor and four FGH trisaccharide acceptor blocks, which can be built up from only eight monosaccharide units.

For large scale synthesis of monosaccharide sulfonic acids $15,25,26$ and 28, an effective method was developed including nucleophilic substitution of the corresponding glucoside-6-O-triflate with lithiated ethyl methane-sulfonate. This reaction was excellent for the synthesis of $O$-glucoside derivative (Scheme 5.) and we produced unit $\mathbf{H}$ (15) in almost 10 grams. The synthesis of the target molecule 15 by using ioidine as a leaving group (12) was also attempted. Although the synthesis was sucsessful, the efficacy of this route was low.

Starting from $\alpha$-thioglucoside derivative 17 we could synthesize the unit $\mathbf{F}$ with high yield using 2-NAP as the temporary protecting group. Additionally we also used PMP group for temporary protection (Scheme 5.). 
The synthesis of monosaccharide sulfonic acid unit $\mathbf{D}$ was carried out also from the $\alpha$-thioglucoside derivative $\mathbf{2 8}$. We prepared the target molecule $\mathbf{2 8}$ with an excellent yield and nearly in 10 grams (Scheme 6.).

The synthesis of DE disaccharide containing a sulfonic acid moiety (32) was completed in large scale in a chemo- and stereoselective way (Scheme 7.). A wide variety of glycosyl donors $(6,7,8)$ and promoters were tested in the glycosylation of units $\mathbf{D}$ and E. Formation of an aglycon transfer side product $(\mathbf{3 3} \alpha, \beta)$ was observed when glycosyl bromide (30) and $\beta$-thioglycoside (29) were used as the donors (Scheme 7.). This competitive side reaction could be avoided with the use of $\alpha$-thioglycoside at a low temperature and a short reaction time.

Based on our previous experiments, the suitable DE disaccharide was prepared in appropriate amount for the pentasaccharides which do not contain sulfonatomethyl moiety on the unit $\mathbf{D}$.

We carried out the formation of two diaccharide acceptors GH $(40,41)$ by the glycosylation of units $\mathbf{H}(\mathbf{1 5}, \mathbf{3 5})$, with the 1-idose derivative (34), and subsequent formation of the 1-iduronic acid moiety at a disaccharide level (Scheme 8.).

FGH trisaccharide acceptor precursors (47-50) were prepared by condensation of $\mathbf{G H}$ disaccharide acceptors (40, 41) and $\mathbf{F}$ monosaccharide donors $(28,42)$ respectively. In all cases the promoter was TfOH-NIS system, and except for synthesis of 44, the coupling reactions took place with good yields. We could increase the yield of derivative 44 to $73 \%$ by using AgOTf-NIS as the promoter. FGH trisaccharide acceptors were achieved by removal of the 2-naphtylmethyl group from the position 4 of unit $\mathbf{F}$ (Scheme 9.).

We synthesized the target pentasaccharides (6-10) and the pentasaccharide trisulfonic acids (51) in protected form by the glycosylation of the FGH trisaccharide acceptors (47-50) with DE disaccharide donors $(32,51)$ respectively. All glycosylation reactions took place in a stereoselective way and we obtained the products in good yields (Scheme 10).

Second part of my work was the transformation of the pentasaccharide trisulfonic acid (51) into the trisulfonic acid end-product (5) in eight steps, in $100 \mathrm{mg}$ scale (Scheme 11).

This compound was utilized by our co-workers for antithrombin-carbohydrate interaction studies. Threedimensional structures of the free and AT-bound forms of the trisulfonate analogue were determined by using different NMR spectroscopic data and molecular dynamics simulations (Scheme 12.). A significant difference in the structure and the conformational flexibility of the idraparinux and its analogue was observed. There is also a notable difference in the 3D structures of the free and bound form of the trisulfonic analogue, revealing that a change in the conformation is required for the activation of antithrombin.

As a continuation of my $\mathrm{PhD}$ work, I plan to convert the protected pentasaccharides into the corresponding idraparinux-analogue end-products. We have already started the modification of pentasaccharide $\mathbf{8}$ which contains sulfonic acid moieties on units D and F (Scheme 13). 